\title{
ETHICAL ASPECTS OF SOCIAL WORK IN MODERN SOCIETY
}

\author{
Hermína Mareková ${ }^{1}$
}

\begin{abstract}
The basic principle for the exercise of professional social work is the respect for human rights and social justice. The social worker's activity is associated with high expectations on the part of society, although the moral standards of society are typically on a lower level. The legislative environment or norms governing the decisions of social workers are determined by legislation as well as generally applicable ethical norms. In practice, this creates ethical dilemmas consisting in the acceptance of a hierarchy or priorities of individual norms, whereas the adopted and applied values and norms can be counterproductive. This situation may cause a conflict between professional ethics and valid social norms. The following article tackles the issues in social work arising from the stereotypes surviving in society and a lack of competence of many social workers.
\end{abstract}

UDC Classification: 364-2; DOI: http://dx.doi.org/10.12955/cbup.v5.1012

Keywords: ethics, human dignity, morality, social work, values

\section{Introduction}

The concept of ethics and its dimensions have probably been a subject of interest for each of us. These issues have been tackled in many different publications, as evidenced by the fact that upon entering the word ethics in the Google Scholar search engine, the number of results referring to this topic for the year 2016 is 133,000 in 0.08 seconds and the word morals yields 25,400 results in 0.06 seconds. Even in everyday life, people increasingly face a variety of serious ethical issues and dilemmas, and stand before a decision. They must often make decisions and every decision may have an ethical aspect with various consequences. We daily hear from the media that this or that contradicts medical, judicial or teaching ethics. It seems as if some professions were supposed to be more ethical than others. As if there could and should be a distinction between professional ethics and valid social norms. The truth is that a certain norm applies in public and another one at home, behind the closed doors of our apartments and houses. This is a Slovak reality surviving from the time of socialism. But this double standard of society, its schizophrenia, has very detrimental consequences in the long term, because this atmosphere is where a new generation socializes. We usually refer to ethics, to moral principles, and we can say for sure what is ethical and what is not, based on our values, valid norms of our society that we have acquired during our education, our socialization.

Socialization has for some time been considered a key factor in the functioning of society and an important attribute for achieving authentic being. In practice, this produces ethical dilemmas consisting in the acceptance of a hierarchy or priorities of individual norms, while the adopted and applied values and norms can be counterproductive. This condition may cause a dilemma between professional ethics and valid social norms.

These are the ethical dilemmas that, if we recognize them, still offer an opportunity to correct our behavior in a timely manner and prevent more serious damage. In this case, it can also be a discriminatory behaviour towards a person who is dependent on our help, so that we have a better argument than the one by Bertrand Russell (1956): "I cannot see how to refute the arguments for the subjectivity of ethical values, but I find myself incapable of believing that all that is wrong with wanton cruelty is that I don't like it." It is becoming ever more desirable for us to pay more attention to ethical dilemmas not only in the field of social work, but in other humanities as well.

\section{Ethics Or Ethics In An Unethical World - Social Work}

The word ethics comes from the Greek word ethos "character, moral nature." Philosophically, it is the discipline or teaching about responsible behavior within the human society (Petrusek et al., 1996, p. 269). There is an interesting term introduced by M. T. Cicero: philosophia moralis from Latin mos "custom, manner," an expression that replaced the term ethics in classical antiquity and scholastic philosophy. According to a sociological dictionary, the term morals means "settled patterns, behavior, generally accepted norms." In the same way the terms manners, customs are used. W. G. Sumner wrote in 1906 that, in his opinion, morals are formed from customs and traditions (volkways) and are based not only on generally accepted stabilized activities, but also on abstract moral principles. They

\footnotetext{
${ }^{1}$ Danubius University, Sládkovičovo, Slovakia, hermina.marekova@gmail.com
} 
are subject to stronger social control (ibid, p. 653). According to other sources, ethics (Greek ethos "moral character") is the sum of all the principles upon which the correctness of acting is assessed (Jandourek, 2001). From the above definitions, the term ethical may not fully express the intended objective, responsible behaviour and habit (stereotype).

With some authors, such as Dupré (2007), we find ethics in conjunction with moral philosophy, which is divided into three areas. The most general one is meta-ethics which explores the origin or basis of morality and asks whether ethics is objective or subjective. The second one is normative ethics, which examines the norms, standards underlying the moral behavior, for example utilitarianism, based on the standard of benefit. The third area, according to him, is applied ethics, which applies a philosophical theory in practical, everyday issues, such as the question of just war, the attitude towards abortion or to animal abuse. In this area, we have seen different ethical attitudes. There is the absolutist stance, according to which deeds are either right or wrong, in all circumstances. The consequentialist argues that the correctness or incorrectness of acts can be assessed only by reference to their effectiveness (utilitarianism). The deontologist considers acts as intrinsically right or wrong, regardless of consequences. Their meaning is associated with the intention of the actor (Kantian ethics). The naturalist believes that ethical concepts can be analysed and identified with the help of science. The non-cognitivist says that morality is not a matter of knowledge, because it ignores facts (emotivism, prescriptivism). The objectivist says that moral values are part of the inventory of the universe, independently of all humans, and ethical concepts are metaphysically true. The subjectivist claims that value has no basis in the external reality. An example of subjectivism is relativism.

According to Hume (Hume's guillotine, Hume's Law), we believe, on the one hand, that we live in a material world that can be explained through science, in a world of facts, out of which value is excluded. On the other hand, we feel that in making moral judgment, e.g. that genocide is wrong, we declare something true about the world, regardless of how we feel about it (In Dupré, 2007).

According to some authors, our morals arise from our prejudices. The term prejudice comes from Latin praejudicium (pre-reasoning, antipathy). According to Giddens (2006), prejudices are our preformed opinions, inflexible, ossified evaluation, customary ideas of another person or group that are not based on experience. They are mostly adopted opinions that keep forming constantly and stubbornly, despite changes, and are maintained. Strictly set expectations and norms form the basis for discrimination (including the gender-based one).

\section{Culture - Values - Value Change}

Culture is a "sum of spiritual and material values created by humankind throughout its history" (Buchtelová et al., 1997, p. 526). Each society has its own culture and these cultures can be very different. Cultural values existing in our society may not apply in other cultures. However, due to constant interaction with social environment, they are subject to constant change.

An important, now increasingly topical issue, says Huntington (1996), is the question if the liberal values of the West are truly universal, or it is just our opinion. In sociology, the elements of culture are the norms and values existing in society. Values and value orientations are the ideas of people about what in society is regarded as good and desirable or, conversely, as bad and undesirable. From the perspective of sociology, the values and norms are very important elements of culture, because, for the functioning of society, it is necessary that its members adhere to certain regulations and norms (Mareková, 2013). The norms define a person's behavior in a certain situation. Without these social norms (which can be understood as conventions), collaboration in society is impossible. Noncompliance to norms results in unpredictable behavior of the members of society. This also prevents cooperation. Violation of a norm is always followed by a penalty.

Adoption of norms takes place during upbringing, which is called socialization in sociology. According to a psychological definition, it is the time of personal development (Hurrelmann, 1988). According to Durkheim (1984), a norm is an elementary component of social existence of humankind. On the one hand, there are the norms of society, on the other hand, the behavior and conduct of a member of a group that should correspond to valid norms of society as much as possible (Ondrejkovič 1998).

Andorka (2003) speaks about the five most important facts in connection with norms: 
1. Norms in a society can be contradictory. For example, criminal law punishes an act, and the majority of citizens are morally opposed to the sanction (they disagree e.g. with sanctions for speeding). Contradictory norms can be adopted by different groups, for example religious or ethnic ones.

2. Norms are constantly changing during the development of society.

3. Various societies adopt different norms. (e.g. vendetta)

4. The fact that a particular society has accepted a norm, does not necessarily mean that that norm is profitable in terms of the existence and development of the particular society, such as the holy cow slaughter ban in Hinduism.

5. During the development of society, norms are subject to constant change, so it is very difficult to assess the behavior of a certain society in the past and consider it negative just because it contradicts the currently accepted norms in the society or collides with the criminal law.

The question arises whether there are also norms that are valid in every society, in every age. Certain moral values could be such (Andorka, 2003). It seems that certain taboos are generally accepted (incest, child abuse).

Empirical evidence shows that changes in our values scale are oriented towards materialism and individualism, while solidarity has fallen on a lower place, below materialism. This question was answered by Inglehart - Abramson (1995) in four points: According to them, the materialist is a human who puts material values on the first two places, while the post-materialists is someone who puts two post-materialist values of the first two places. According to Inglehart and Abramson (1995), the number of post-materialists has increased in every western country since the seventies. Not everyone agrees with their opinion and most sociologists hold the view that changes in values are cyclic and that a "hippie" society is followed by a "yuppie" one, which puts more emphasis on material values. According to Hankiss (1983), a negative modernization took place in post-communist countries: in the case of individualization, society has progressed much faster, while in other indicators, such as work efficiency, independence and innovativeness, the post-communist countries have fallen behind other modern societies.

"Our ideals are constantly changing," wrote Fritz Bohnsack in 1996 and said that significant changes in the recognition of previously existing values have occurred in his country. According to him, a few decades ago the accepted, recognized, valid values and norms in society used to be qualities such as submission, discipline, performance of duties, reliability, openness, loyalty, punctuality, self-sacrifice for the good of society, and modesty. German sociology calls them the values of duty and acceptance. The new values are called the values of self-actualization. Such values include spontaneity, pleasure seeking, self-fulfilment, and immediate satisfaction of someone's needs. "Not everyone accepts it, but most of society lives according to it," says Bohnsack (1996). In general, there are certain values and norms that have been, are and perhaps will be valid in every society and they are called taboos. Taboos in most cultures include incest, child abuse and such. (Mareková, 2014).

\section{Social Identity - Socialization}

Identity comes from Latin identicus "identical." In general, it is the unity of inner, mental life and action - also called authentic existence. The term is used in various meanings. E. H. Erikson (1955) uses it as a concept of an essential feature of adolescence, which is associated with questions such as Who am I? Am I adult? A. H. Maslow (1954), a humanist psychologist, defines it as the ability to be what I really am, i.e. myself. It is the pursuit of self-actualization. In social psychology, identity is broadly understood as authentic being. Its opposite is an inauthentic being that is hypocrisy. In philosophical anthropology, identity is understood as "living in truth." In sociology, identity is discussed by R. G. Darendorf (1950) and E. Goffman (1959). (In: Petrusek - Vodáková, 1996, p. 414)

Socialization (from lat. socialis - sociable, allied, marital) is a complex process during which the human as a biological creature becomes, by means of social interaction and communication with other social beings, able to behave as a member of a group (ibid.). Socialization is a lifelong process, a lifelong interaction of the individual with their environment. The adoption of norms takes place during upbringing, which is termed socialization in sociology and represents acquiring the values and norms of a society. 
According to a psychological definition, it is the time of personality development. Meeting norms happens often because people are afraid of sanctions, but it can also take place because these norms are identical with their value orientation (internalization), therefore they comply with them without any control or sanctions, or condemn the individual who does not respect them (Mareková, 2013). Socialization after Brimm (1966) is the process, in which an individual acquires such knowledge, skills and abilities that enable them to become a more or less useful member of various groups or society.

Awareness of the Self is a process that begins in early childhood. Within it, I differentiate myself from "the others." The development of our personality, ourselves, is a process that accompanies us since our birth, when we have no idea of society, and throughout our lives, as Parsons wrote in his publication back in 1956: " The birth of every new generation of infants is a recurrent barbarian invasion..., because the newborn does not have the slightest idea about the rules and norms of the society in which s/he was born."

Socialization has for a longer period been considered a key factor, a very important element of the functioning of society and an important attribute in achieving authentic being. The process of socialization was covered by Freud. According to him and his classical psychoanalysis, the essence of socialization is a suppression of social and biological instincts, of animal sexuality and aggression. In other words, a creation of impulse control.

According to Hartman, socialization is a process of acquiring the ability to adapt. English empirical philosophy (Locke, Hobbes), as well as Skinner, assumed that the human socializes solely on the basis of interaction with their social environment. According to social psychology, we socialize under environmental influences - by learning.

Modern theories talk about learning roles according to society's expectations. Of course, all of these factors are crucial for our behavior at a later stage, but, from the point of view of a social worker, they can also produce an unwanted behavior. Europe has always been more or less homogeneous and the principle of the nation state has been customary: Germany used to be inhabited by the Germans and England by the English. This has changed with the arrival of large numbers of people with completely different cultures. The skills acquired during socialization do not provide us a comfortable climate anymore and we are beginning to feel lost in our carefully constructed world. But then we form the ground for fear and for other attributes, such as prejudices, discrimination, aggression, and violence.

\section{Ethical Code - Values In A Valueless World}

Professional ethical codes contain sets of ethical rules that society expects from the workers in a profession and they should also include sets of rules and sanctions for those who do not meet these expectations. They are actually sets of rules about what is good and right and expected by society. Most professions nowadays have such a set of rules. Problems arise when the individual values contradict or some norms are no longer valid.

In the now obsolete Code of Ethics of Social Work from 1997, the Preamble of social work stated that "...the social workers are also guided by the norms they formulate themselves" That was a source of problems, because socialization and the accepted norms of individuals can be very different. Not to mention the fact that it contradicted the subsequently adopted international documents. The issue consisted in differences of formulating one's own values based on the accepted culture, socialization (upbringing), multicultural environment, etc... The question is whether we can create a "timeless" code of ethics, because the determinants defining our values and norms are constantly changing. The Code of Ethic of Social Work should be in line with the values of the European Union and the legislation, which is part of the Treaty of Amsterdam. A code of ethics can be formed only on the basis of respect for human rights and norms, social justice, international codes and anti-discrimination.

\section{Dilemmas In Social Work}

What is a dilemma? It is a "necessity of choosing between two mutually exclusive (often unfavorable) options," or, in logic, a syllogistic judgment with two implicative and one disjunctive premise" (Buchtelová et al., 2008. p. 215). These are often hidden problems, difficulties creating tension. Dilemma is such a need of choice, when we do not have sufficient information, or what we have is contradictory. Theoretically, these dilemmas have long been tackled in various postulates, but we must realize the importance, the necessity of resolving these problems in practice, the more so that 
dilemmas arise in everyday practice, mainly in communication, and it is there where they should also be addressed.

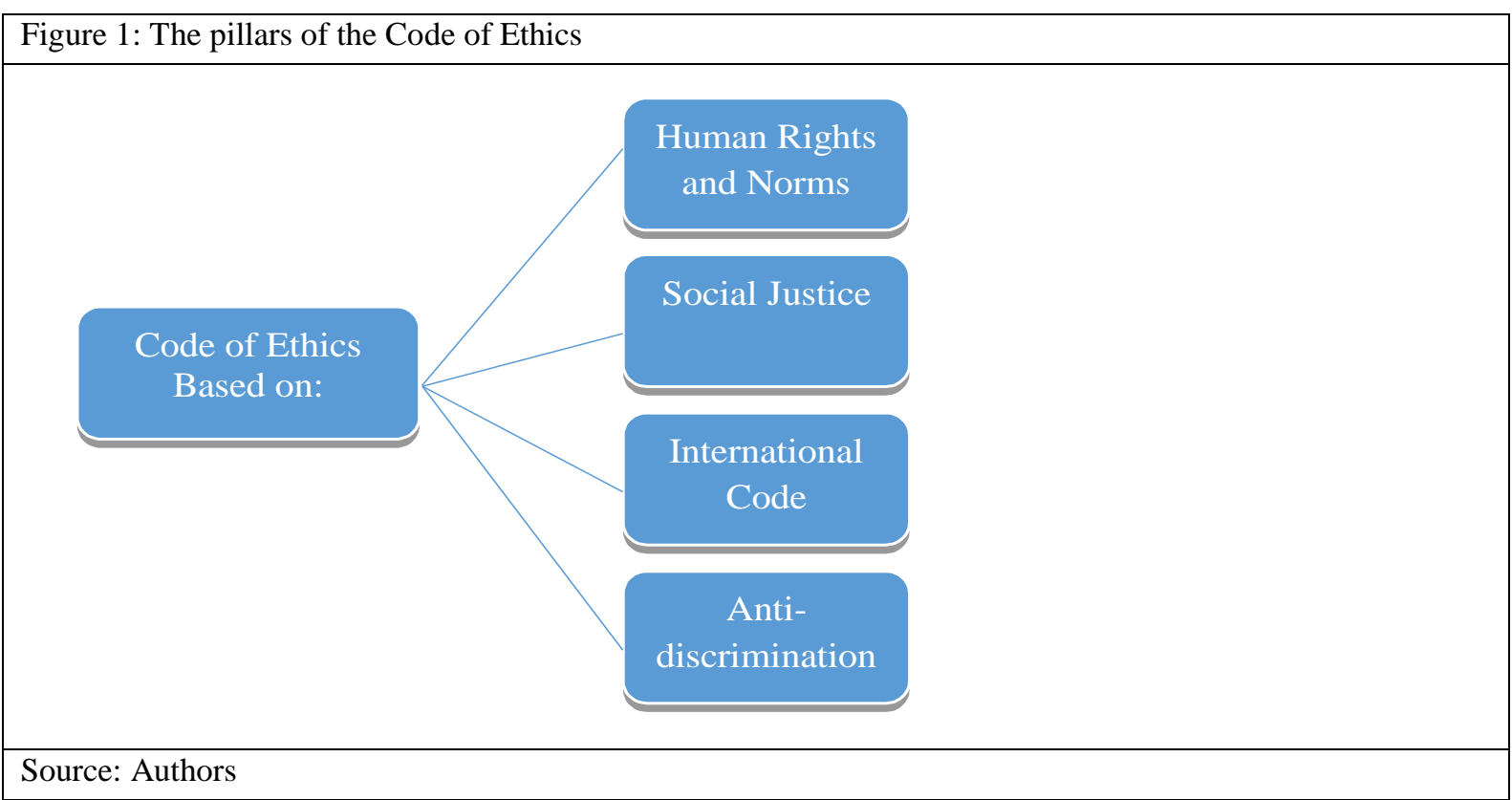

In social work, ethical dilemmas arise from the acceptance of a hierarchy or priorities of individual norms, while adopting and applying certain values and norms can be counterproductive. This condition may cause a dilemma concerning the relationship between professional ethics and valid social norms. The social worker must often make a decision, even in a situation where they do not have enough information, or the pieces of information come from various sources (e.g. the media) and are contradictory. When this is the case, information is untrustworthy and cooperation is difficult or even impossible. Dilemmas arise on the professional level (lack of competence), on a personal level (patterns, models) as well as in the social and cultural field (traditions, values, stereotypes). They can also occur in the field of politics.

According to Banks (2006), there is a difference between ethical issues and dilemmas. She thinks that an ethical dilemma arises when we must choose between equally unfavorable alternatives that are contradictory to our moral principles and it is not clear, which option is the right one, and regardless of our choice, it will leave us in anguish and remorse. According to her professional ethics, we must constantly re-evaluate.

An ethical dilemma arises when a social worker faces one or more contradictory values. The very first one is the dilemma of intervention or non-intervention. What takes precedence? Justice or equality, efficiency or competence, or the right to self-determination? Is good what society expects, or what we have learned during socialization? There is a very strong and complex pressure from society. Every action has a broader perspective, as in the case of an alcohol addict: assistance is needed by the whole family and there are both objective and subjective elements. Objectivity is necessary, lest social workers are not only amateurs, writes Max Weber (1970). An amateur differs from a professional only in that $\mathrm{s} / \mathrm{he}$ is not sure about the firmly established working methods, and therefore mostly unable to control, assess or realize the significance of their ideas.

These tensions and dilemmas are being developed in various fields, such as professional and personal environments, social, political, cultural areas etc. According to some sociologists, for example Bauman (2000), they are "liquid modernities," because they reinforce individualization. According to Giddens (1994, p. 5), the growing reflexivity results in a reduced respect for traditions and a growing importance of communication. He thinks that the more tradition weakens, the more one is forced, for various reasons, to make personal choices in one's life (possible ethical dilemmas). There are big debates about the common values: if they are receding, or social solidarity is being reduced (Putnam, 2000). 
The performance of social work is a long process with the human and is completely different from the direction of the society development, which is focused on results and, where possible, immediate ones. Among other dilemmas is the question of the worker's motivation in a society where this work is extremely undervalued, both financially and socially.

\section{Gender Sensitive And Gender Insensitive Social Work}

Even social work can be discriminatory, if it is carried out under these deterministic ideas. Nonstereotypical, gender sensitive social work can be promoted only on the basis of respect for human rights and norms, social justice and anti-discrimination (Mareková, 2013b).

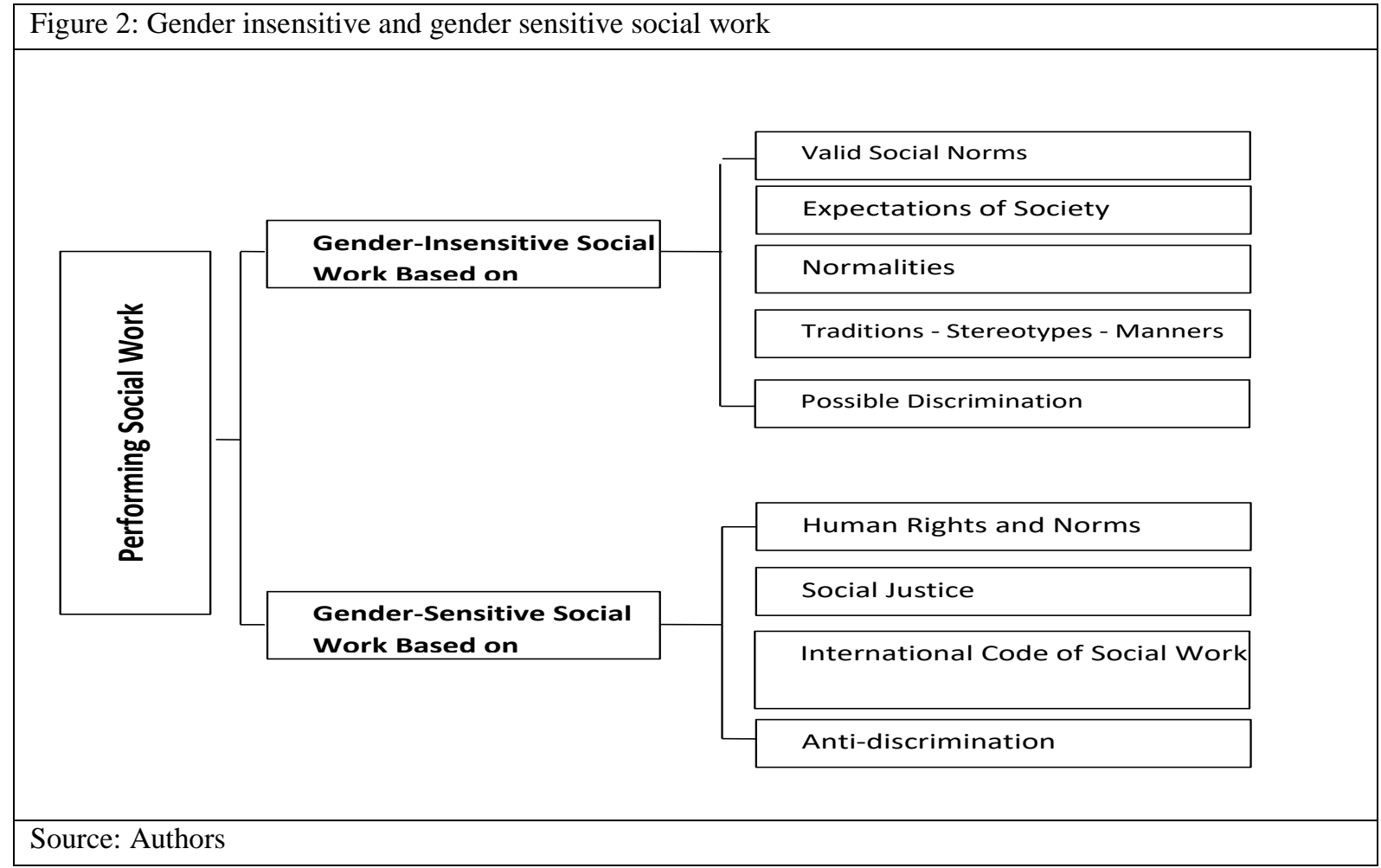

\section{Conclusion}

"Imagine us living in a world where no one ever imposes anything, where there is peace and open possibilities for all," says Watkins (2000). We all long for the same, but we often expect solutions from others. We live in a time when our consumption of material goods far exceeds our real needs and, as Dorian Grey said, we need only unnecessary things. We are unable to set our priorities and give up some of the material achievements. We have rich choices at the disposal, but do we really need 35 programs in the washing machine, when we use only three of them, or a hundred TV channels, when we usually watch about five? And do we exploit the full potential of our "superphones"? Instead of true values, we seek trendy advances in science and technology, in accordance with society's expectations. We often spend a long time exploring various technical achievements, which limit our freedom and make us slaves of materialism. We balance between understanding how to secure freedom for people in decision-making and between the expectations of society in instances where social values and institutions are at risk. On the one hand, society is supposed to provide every human with achievable options and, on the other hand, the social worker does not have sufficient competence, time, personal capabilities or financial provision. Practical experience shows that during the performance of not only social work, but also various other professions, the existing international legislation on racism, discrimination and gender bias is violated on the part of social workers. This happens both because of unpreparedness (ignorance), but also because of the maintained stereotypes in society. We lack a unified vision and an ethical, normative and legislative uniformity, within which the work should be done, despite the determinants shown above. 


\section{Acknowledgements}

This scientific article was created within the operational program "Research and Development" for the project "Modernization and Building Technical Infrastructure to Support and Develop the Scientific and Research Potential of Danubius University, Sládkovičovo."

ITMS 26210120047. The project is co-financed by the European Regional Development Fund. Research Agency of the Slovak Ministry of Education.

\section{References}

Andorka, R. (2003). Bevezetés a szociológiába (p. 656). Budapest: Oziris.

Banks, S. (2006). Ethics and Values in Social Works (3rd ed.). Basingtoke: Palgrave MacMillan.

Bauman, Z. (2000). Liquid Modernity. Cambrigde: Polity Press.

Bohnsack, F., \& Leber, S. (1996). Sozial-Erziehung im Sozial-Verfall (p. 384). Weinheim: Beltz.

Brimm, O. G. (1966). Socialization throughout the Life Cycle. In: Brimm, O., \& Wheeler, S. (Eds.). Socialization After Childhood. New York: John Wiley

Buchtelová, R., Confortiová, H., Červená, V., Holubová, V., Hovorková, M., Churavý, M., Kraus, J., Kroupová, L., Ludvíková, M., Machač, J., Mejstř́k, V., Petráčková, V., Poštolková, B., Roudný, M., Schmiedtová, V., Šroufková, M., \& Ungermann, V. (2008). Slovnik cudzích slov (3rd ed., p. 1054). Bratislava: SPN - Mladé letá, Ltd.

Code of Ethics of Social Worker (1997). Žilina: ASPS. In: Mátel, A. et. al. (2012). Etika sociálnej práce (2nd, revised and updated edition, pp. 251-253). Bratislava: St. Elizabeth College of Health and Social Work.

Dupré, B. (2011). Filozofia. Bratislava: Slovart, Ltd..

Durkheim, E. (1984). Erziehung, Moral und Gesellschaft. Frankfurt a. M.: Suhrkamp.

Giddens, A. (1994). Living in a Post-Traditional Society. In: Beck, U., Giddens, A, \& Lash, S. Reflexive Modernization (p. 56-109). Cambrige: Polity Press

Giddens, A. (2006). Sociology. (5th ed.). Cambrige: Polity Press.

Hankiss, E. (1983). Társadalmicsapdák. Diagnózisok. Budapest: Magvető Kiadó.

Hume, D. (2007). Hume's guillotine - Hume's Law. In: DUPRÉ, B. (2011). Filozofia. (pp. 48-51). Bratislava: Slovart, Ltd.

Huntington, S. P. (1996). The Clash of Civilizations and the Remaking of World Order. New York: Simon \& Schuster

Hurrelmann, K. (1988). Social Structure and Personality Development: The Individual as a Productive Processor of Reality. Cambridge: Cambridge University Press.

Inglehart, R., \& Abramson, P. R. (1995). Value Change in Global Perspective. Ann Arbor: University of Michigan.

Jandourek, J. (2001). Sociologický slovnik (p. 288). Praha: Portal.

Mareková, H. (2013). Rodovo citlivá sociálna práca v kontexte s etickým kódexom sociálneho pracovníka SR. In: Mátel, A., \& Grey, E., \& Janechová, L. (eds.) (2013). Aplikovaná etika 2. 107 Zborník z medzinárodnej vedeckej konferencie (p. 364). Bratislava: St. Elizabeth College of Health and Social Work.

Mareková, H. (2013b). Glosár pojmov rodovej rovnosti, rovnosti príležitostí a rodovo citlivej sociálnej práce pre sociálnych pracovnikov / Glossary of Gender Equality, Equal Opportunities and Gender-Sensitive Social Work for Social Workers. Trnava: Oliva.

Mareková, H. (2014). Sociálna práca s týranými ženami a pretrvávajúce inštitucionálne problémy pomoci. In: Zborník konferencie Vizualizácia sociálnej práce (2015). Sládkovičovo: Danubius University.

Ondrejkovič, P. (1998). Úvod do sociológie výchovy. Teoretické základy sociológie výchovy a mládeže (p. 381). Bratislava: Veda.

Parsons, T., \& Bales, R. F. (1956). Family socialization and Interaction Process. London: Routledge and Kegan Paul.

Petrusek, M., \& Vodáková, A. (1996). Vel'ký sociologický slovník I., II. (1st vol.). Praha: Karolínum.

Putnam, R. (2000). Bowling Alone. New York: Simon and Schuster.

Russell, B. (1956). Logic and Knowledge. Essays, 1901-1950. Ed. by Robert Charles Marsh. London: George Allen and Unwin Ltd and New York: The Macmillan Company.

Sumner, W. G. (1906). Sumner g. (1906). folkways. bostonginn. In: Petrusek, M., \& Vidáková, A. (1996). Vel'ký sociologický slovnik I., II., (1st volume). Praha: Karolínum.

Watkins, G. J. (Bell Hooks) (2013). Feminism is for Everybody. Feminizmus do vrecka. O zanietených politikách. Bratislava: Aspekt.

Weber, M. (1970). Állam, politika, tudomány. Budapest: Közgazdasági és Jogi Könyvkiadó. 